\author{
Tetiana Zosymenko $^{1 \times}$, Vitalii Rybchak ${ }^{2}$ \\ ${ }^{1}$ Chernihiv National University of Technology \\ ${ }^{2}$ Uman National University of Horticulture
}

\title{
Opportunities to increase Ukrainian export competitiveness in the European Union market
}

\begin{abstract}
Summary. The National Export Strategy (NES) of Ukraine in 2017 is aimed at increasing the competitiveness of exports. The EU market is identified as a priority market. The purpose of the study is to define the directions of trade cooperation between Ukraine and the EU, which will allow to increase Ukrainian export competitiveness in the EU market and will be mutually beneficial for the trade partners. To solve this problem, the current model of trade cooperation between Ukraine and the EU has been analyzed and characterized. The results of the study indicate that the priorities of national trade policy within the context of EU trade are: stimulation of the production of niche products of the food and beverages industry; support of qualitative integration of the domestic machinery into European value chains; promoting the development of European technologies mastering and intra-branch trade upbuilding in the aerospace and aviation parts and components industry.
\end{abstract}

Key words: market, competitiveness, export, National Export Strategy, globalization

\section{Introduction}

Ukraine is a "newcomer" among the main subjects of world trade space. It is just forming a foreign trade model that is adequate to the objective processes of globalization and international economic regionalization. The majority of theories of international trade (the theory of comparative advantages of D. Ricardo ${ }^{1}$, the Heckscher-Ohlin theo$\mathrm{rem}^{2}$, the theory of the product life cycle ${ }^{3}$, Porter's national Competitive Advantage $\mathrm{Model}^{4}$, etc.), using different arguments, prove that foreign trade a priori benefits both the exporting country and the importing country. However, to grant the truth of what

\footnotetext{
${ }^{1}$ D. Ricardo: The principles of political economy and taxation, Dover Publications, Mineola NY 2004.

${ }^{2}$ R. Findlay: Eli Heckscher, international trade, and economic history, MIT, Cambridge MA, London 2006.

${ }^{3} \mathrm{R}$. Vernon: International Investment and International Trade in the Product Cycle, Quarterly Journal of Economics 1966, No 80(2), p. 190.

${ }^{4}$ M.E. Porter: On competition, Harvard Businesss School Publishing, Boston MA 1998.

tetiana.zosymenko@gmail.com
} 
has been said, trading partners should have the sufficient and comparable level of competitiveness. A country will benefit from international trade even with a negative foreign trade balance provided that its economy is sufficiently competitive and favorable for foreign investment. As a result, both countries become richer, create better jobs and produce more goods and services in areas where they have competitive advantages ${ }^{5}$.

\section{Methodology}

The main purpose of this study is to describe the model of the trade relations between the EU and Ukraine in order to increase Ukrainian export competitiveness. This model is regarded as a perfect sample of commercial relations in response to the deepening economic integration and under the free trade area. The important component of the model is "sensitive goods". These are the commodities with high level of competition between the European and Ukrainian producers within the priority export sectors. The list of such goods should be taken into account before the adoption of trade policy measures. Therefore, trade dimension of competition between the EU and Ukraine, emerging from the understanding of their economic interests, is designed to mutually benefit both sides.

\section{Development}

Today the principle of mutual benefit in international economic relations is the main and the most general principle of law, on which a whole international cooperation is built ${ }^{6}$. But currently export of the EU countries is much more competitive then the Ukrainian one. The competitiveness of exports is one of the most important indicators of competitiveness of the country. Among the main determinants of export performance UNCTAD experts highlight the access to foreign markets. The main indicator reflecting this is the export share of the country in international markets ${ }^{7}$. To that end, Table 1 provides an overall picture of the competitiveness of exports of Ukraine and the $\mathrm{EU}$ in the main commodity groups.

The EU countries are among Top 20 in the world market in the terms of export volumes of each commodity group. According to Export Strategy of Ukraine (ESU) ${ }^{8}$ there are several important EU markets that offer untapped export potential opportunities. Among them are Germany, France and Ireland. These countries have significant competitive advantages both in the spheres of trade in traditional products of Ukrainian

\footnotetext{
${ }^{5}$ M. Cox, R. Alm: Myths of Rich \& Poor, [in:] Debating Democracy, B. Miroff et al. (Eds.), Houghton Mifflin, Boston, MA 1999, pp. 320-326.

${ }^{6}$ O. Mikichurova: Implementation of the principle of mutual benefit in the process of Ukraine's integration into the European Union, Legea Si Viata 2015, No 4/3(280), pp. 57-62.

${ }^{7} \mathrm{M}$. Fugazza: Export Performance and its Determinants: Supply and Demand Constraints, United Nation, New York, Geneva 2004.

${ }^{8}$ Export Strategy of Ukraine: Strategic Trade Development Road Map 2017-2021, http://me.gov.ua/ Documents/Detail?lang=uk-UA\&id=e6ab10fa-0ad9-4fe4-b8be-32f570693b64\&title=EksportnaStrategiiaUkraini-DorozhniaKartaStrategichnogoRozvitkuTorgivli2017-2021 (access: 30.09.2018).
} 
Table 1. Comparison of Ukraine's and the EU's export position in 2016

\begin{tabular}{|c|c|c|}
\hline Commodity group & $\begin{array}{l}\text { Place of Ukraine } \\
\text { among the expor- } \\
\text { ting countries }\end{array}$ & $\begin{array}{l}\text { The EU countries that are in Top } 20 \text { in the world } \\
\text { market in the terms of export volumes of the com- } \\
\text { modity group (ranking) }\end{array}$ \\
\hline Agricultural products & 26 & $\begin{array}{l}\text { the Netherlands (2), Germany (3), France (6), Spain } \\
\text { (8), Belgium (9), Italy (10), Poland (18) }\end{array}$ \\
\hline Automotive products & 67 & $\begin{array}{l}\text { Germany (1), Spain (7), France (9), Belgium (11), } \\
\text { Italy (12), the Czech Republic (13), Poland (15), the } \\
\text { Slovak Republic (16), Hungary (17), Sweden (18), } \\
\text { the Netherlands (19), Austria (20) }\end{array}$ \\
\hline Chemicals & 63 & $\begin{array}{c}\text { Germany (1), Belgium (4), the Netherlands (6), } \\
\text { France (7), Ireland (8), Italy (10), Spain (12), Austria } \\
\text { (19), Denmark (20) }\end{array}$ \\
\hline Clothing & 58 & $\begin{array}{l}\text { Italy (3), Germany (5), Spain (8), France (9), Bel- } \\
\text { gium (10), Germany (18), Denmark (20) }\end{array}$ \\
\hline EDP and office equipment & 56 & $\begin{array}{l}\text { the Netherlands (4), Germany (5), the Czech Repu- } \\
\text { blic (11), Ireland (18), France (19), Hungary (20) }\end{array}$ \\
\hline Food & 26 & $\begin{array}{l}\text { the Netherlands (2), Germany (3), France (5), Spain } \\
\text { (7), Belgium (9), Italy (10), Poland (17) }\end{array}$ \\
\hline Iron and steel & 11 & $\begin{array}{c}\text { Germany (3), Italy (6), France (9), Belgium (10), the } \\
\text { Netherlands (12), Spain (15), Austria (19) }\end{array}$ \\
\hline $\begin{array}{l}\text { Machinery and transport } \\
\text { equipment }\end{array}$ & 45 & $\begin{array}{c}\text { Germany (2), France (8), the Netherlands (9), Italy } \\
\text { (11), Spain (15), Belgium (17), the Czech Republic } \\
\text { (18), Poland (20) }\end{array}$ \\
\hline $\begin{array}{l}\text { Miscellaneous } \\
\text { manufactures }\end{array}$ & 43 & $\begin{array}{l}\text { Germany (2), France (7), Italy (8), the Netherlands } \\
\text { (9) }\end{array}$ \\
\hline $\begin{array}{l}\text { Office and telecom } \\
\text { equipment }\end{array}$ & 57 & $\begin{array}{l}\text { Germany (8), France (13), Italy (14), the Nether- } \\
\text { lands (15), Belgium (17) }\end{array}$ \\
\hline Pharmaceuticals & 58 & $\begin{array}{c}\text { Germany (1), Belgium (3), France (5), the Nether- } \\
\text { lands (7), Ireland (8), Italy (9), Spain (10), Denmark } \\
(12), \text { Austria (14), Sweden (15), Hungary (19), Po- } \\
\text { land (20) }\end{array}$ \\
\hline Textiles & 64 & $\begin{array}{c}\text { Germany (3), Italy (5), Belgium (12), France (13), } \\
\text { the Netherlands (15), Spain (17), the Czech Repu- } \\
\text { blic (20) }\end{array}$ \\
\hline Raw materials & 63 & the Netherlands (6), Germany (12), Belgium (19) \\
\hline
\end{tabular}

Source: drafted by the authors based on World Trade Organization: Trade and tariff data, https://www.wto.org (access: 20.10.2018).

export and in the spheres, which now are not export-oriented in Ukraine (high-tech goods).

Ukraine demonstrated the best position by exporting commodity groups with low added value (iron and steel products -11 th place, agricultural products -26 th place, food products -26 th place). Instead, Ukraine's positions on external supply of such commodity groups as automotive products (67th place), chemicals (63rd place), EDP 
and office equipment (56th place), machinery and transport equipment (45th place), office and telecom equipment (57th place) testify to the low level of competitiveness in the production of high-tech goods.

The current model of trade cooperation between Ukraine and the EU is characterized by significant disproportions in the technological dimension: primary products, low-technology and resource-based export are dominant in the Ukrainian export structure, medium and high technology import from the EU countries are twice as high as from Ukraine. In order to consider the actual and possible in the future model of the trade relationship between the EU and Ukraine, we will take into account the commodity-economic dimension of competition with an emphasis on the export component. It includes quantitative indicators of volumes, dynamics, commodity and geographical structure of foreign trade. Instead, the technological dimension, which includes the supply of goods and services to the counterparty (logistics), the procedures for documenting the export-import operations, will not be the subject of this study ${ }^{9}$.

The main indicators of the foreign trade between Ukraine and the EU countries in the dynamics are presented in Table 2. Despite the negative trends in the import and export indicators for 2013-2015, it can be argued that the openness of the domestic economic system for the trade with the EU become higher and stronger. Its dependence on the sales of goods in the European market has grown. The catalyst for this, among other things, was the trade preferences accorded to Ukraine due to the provisions of AA/DCFTA.

Table 2. The dynamics of the main indicators of the foreign trade between Ukraine and the EU countries

\begin{tabular}{|c|c|c|c|c|c|}
\hline Year & $\begin{array}{c}\text { Import } \\
\text { (USD thous.) }\end{array}$ & $\begin{array}{c}\text { Share } \\
(\%)\end{array}$ & $\begin{array}{c}\text { Export } \\
\text { (USD thous.) }\end{array}$ & $\begin{array}{c}\text { Share } \\
(\%)\end{array}$ & $\begin{array}{c}\text { Trade balance } \\
\text { (USD thous.) }\end{array}$ \\
\hline 2011 & 25585757 & 31.54 & 17942345 & 26.26 & -7643412 \\
\hline 2012 & 26019278 & 31.27 & 17044240 & 24.82 & -8975038 \\
\hline 2013 & 26801186 & 34.88 & 16866113 & 26.65 & -9935073 \\
\hline 2014 & 20815290 & 39.63 & 17085078 & 31.61 & -3730212 \\
\hline 2015 & 15544862 & 42.48 & 13026397 & 34.14 & -2518465 \\
\hline 2016 & 17099468 & 44.00 & 13495534 & 37.12 & -3603934 \\
\hline
\end{tabular}

Source: drafted by the authors based on State Fiscal Service of Ukraine: Customs statistics, http://sfs.gov.ua (access: 25.10.2018).

The increase in the number of business entities that granted the right to export livestock products to the EU countries shows the attractiveness of the EU market for Ukrainian producers. This provides opportunities for the continuation and acceleration

I. Burakovsky: Ukrainian exports: the results of 2016 and future vision, http://www.ier.com.ua/ua/publications/articles?pid=5503 (access: 20.10.2018). 
of such processes and, in the long run, to substantially improve their qualitative dimension.

Current qualitative dimension of Ukrainian export could not be considered satisfactory (the figure). The main part of Ukrainian export consisted of the ferrous metals (19.9\%), electric machines (11.9\%), grain crops (9.5\%), fats and oils of animal or vegetable origin (8.9\%). The most imported commodity groups were: mineral fuels; oil and products of its distillation $-14.8 \%$; nuclear reactors, boilers, machines $-14.1 \%$; means of land transport, except for railways $-8.5 \%$.

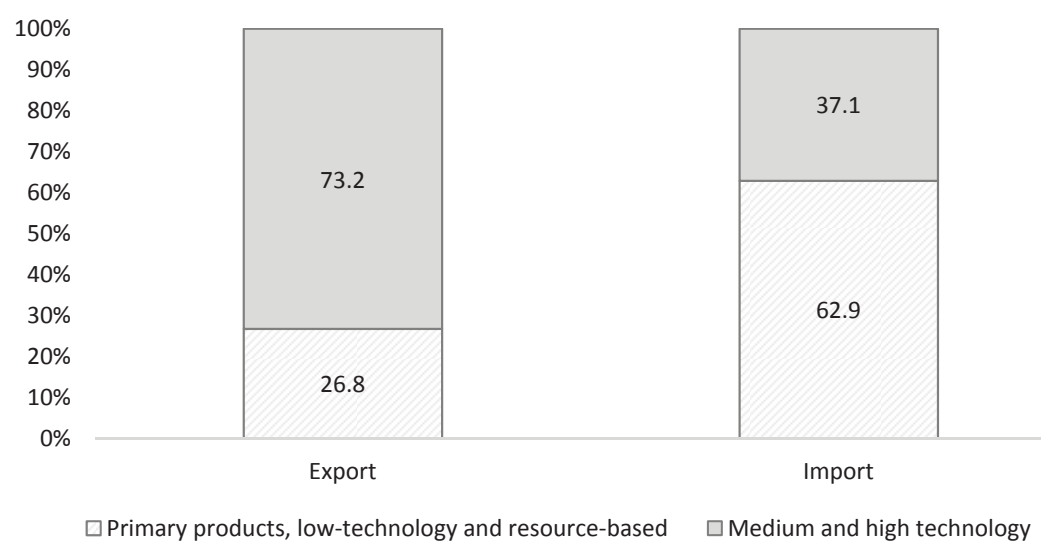

Figure. Technological cross-section of the trade between Ukraine and the EU countries Source: drafted by the authors based on State Statistical Service of Ukraine: Cooperation between Ukraine and EU Countries, External economic activity, Publications, http://www. ukrstat.gov.ua (access: 25.10.2018).

Taking into account the priorities defined in the ESU a matrix of export-oriented sectors of the Ukrainian economy was drawn up. The matrix was developed according to the following criteria: the sector represents economic interest for Ukraine in accordance with the ESU; a commodity group has a big share in the EU import from third countries; Ukraine has significant competitive advantages in the production of the commodity group (Table 3).

Based on the analysis of the foreign trade indicators by the commodity groups within the export-oriented sectors, products with a high level of competition between the EU's and Ukrainian producers were identified. Table 4 shows that there is a list of "sensitive goods" within each of the considered sectors. The import share of such commodity groups from third countries to the EU does not exceed $20 \%$. At the same time, this product group occupies more than $0.1 \%$ of the total export from Ukraine. It means that these goods can become the object of competition between the EU's and Ukrainian producers. Therefore, this list should be taken into account for the mutual consideration of the partners' positions. For example, bilateral consultations are necessary before the adoption of trade policy measures, concerning preferences for the listed commodities. 
Table 3. Matrix of export-oriented sectors of Ukrainian economy

\begin{tabular}{|c|c|c|c|c|c|}
\hline Sector & Commodity group & $\begin{array}{l}\text { Priority } \\
\text { according to } \\
\text { the ESU }\end{array}$ & $\begin{array}{l}\text { Existence of } \\
\text { export during } \\
\text { the last } 3 \\
\text { years }\end{array}$ & $\begin{array}{c}\text { Big share } \\
\text { in the EU } \\
\text { import from } \\
\text { third } \\
\text { countries }\end{array}$ & $\begin{array}{l}\text { Competitive } \\
\text { advantages }\end{array}$ \\
\hline \multirow{5}{*}{$\begin{array}{l}\text { Food and } \\
\text { beverages } \\
\text { industry }\end{array}$} & $\begin{array}{l}\text { foods made from } \\
\text { meat, fish or cru- } \\
\text { staceans, shellfish }\end{array}$ & + & + & + & \multirow{5}{*}{$\begin{array}{c}\text { natural and } \\
\text { climatic con- } \\
\text { ditions, raw } \\
\text { material base, } \\
\text { human capital, } \\
\text { well-established } \\
\text { production and } \\
\text { experience }\end{array}$} \\
\hline & $\begin{array}{l}\text { sugar, sugar prepa- } \\
\text { rations and honey }\end{array}$ & + & + & + & \\
\hline & $\begin{array}{c}\text { cocoa and food } \\
\text { preparations with } \\
\text { cocoa }\end{array}$ & + & + & + & \\
\hline & $\begin{array}{l}\text { cereals and cereal } \\
\text { preparations }\end{array}$ & + & + & - & \\
\hline & $\begin{array}{l}\text { vegetables and fru- } \\
\text { its, nuts prepared }\end{array}$ & + & + & + & \\
\hline \multirow[t]{2}{*}{ Machinery } & $\begin{array}{l}\text { reactors, vapour } \\
\text { generating boilers, } \\
\text { auxiliary plant; } \\
\text { parts }\end{array}$ & + & + & + & $\begin{array}{l}\text { raw material } \\
\text { base, produc- } \\
\text { tion base }\end{array}$ \\
\hline & $\begin{array}{c}\text { electrical machine- } \\
\text { ry, apparatus and } \\
\text { appliances, NES; } \\
\text { video and audio } \\
\text { equipment }\end{array}$ & + & + & + & $\begin{array}{l}\text { scientific base, } \\
\text { labor force }\end{array}$ \\
\hline $\begin{array}{l}\text { Aerospace } \\
\text { and aviation } \\
\text { parts and } \\
\text { components, } \\
\text { including } \\
\text { aircraft }\end{array}$ & $\begin{array}{l}\text { aircraft and asso- } \\
\text { ciated equipment; } \\
\text { spacecraft, etc. }\end{array}$ & + & + & + & $\begin{array}{c}\text { raw material } \\
\text { base, produc- } \\
\text { tion base, scien- } \\
\text { tific base, labor } \\
\text { force }\end{array}$ \\
\hline
\end{tabular}

Source: drafted by the authors based on State Fiscal Service of Ukraine: Customs statistics, http://sfs.gov.ua (access: 25.10.2018); UNCTADstat: Datacenter, http://unctadstat.unctad. org (access: 26.10.2018).

The model of trade cooperation between Ukraine and the EU should be based on the trade policy, which not only takes into account the competitive advantages of the parties, but also allows them to realize their integration capacity. For the implementation of the main directions of the agreed foreign trade policy, the sectors identified as priority by ESU were selected. However, for their inclusion in the mutually beneficial model it is not enough for Ukraine only to increase the export of commodity groups that meet the criteria of Table 3. Increasing the competitiveness of Ukrainian export should take into account opportunities for implementing the integration capacity, which is opened by the free trade area between Ukraine and the EU. 
Table 4. Commodity groups with a high level of competition between the EU's and Ukrainian producers

\begin{tabular}{|l|c|c|}
\hline Commodity group & \multicolumn{1}{|c|}{$\begin{array}{c}\text { Share in the EU import from } \\
\text { third countries } \\
(\%)\end{array}$} & $\begin{array}{c}\text { Commodity group share } \\
\text { in the Ukrainian export } \\
(\%)\end{array}$ \\
\hline \multicolumn{1}{|c|}{ Food and beverages industry } \\
\hline $\begin{array}{l}\text { Butter and other fats and oils } \\
\text { derived from milk }\end{array}$ & 2.99 & 0.1 \\
\hline $\begin{array}{l}\text { Birds' eggs and eggs' yolks; egg } \\
\text { albumin }\end{array}$ & 2.52 & 0.13 \\
\hline Barley & 3.4 & 1.83 \\
\hline $\begin{array}{l}\text { Meal and flour of wheat and flour } \\
\text { of meslin }\end{array}$ & 4.16 & 0.20 \\
\hline Sugar confectionery & 12.14 & 0.29 \\
\hline Chocolate & 8.26 & 0.37 \\
\hline Margarine and shortening & 8.97 & 0.14 \\
\hline & Machinery & 0.1 \\
\hline $\begin{array}{l}\text { Agricultural machinery (excluding } \\
\text { tractors) and parts }\end{array}$ & 19.63 & 0.1 \\
\hline $\begin{array}{l}\text { Motor vehicles for the transport of } \\
\text { persons }\end{array}$ & 17.25 & \multicolumn{1}{|c|}{} \\
\hline
\end{tabular}

Source: drafted by the authors based on State Fiscal Service of Ukraine: Customs statistics, http://sfs.gov.va (access: 25.10.2018); UNCTADstat: Data center, http://unctadstat.unctad. org (access: 26.10.2018).

Given the limited financial resources and the lack of capacity of state institutional support in the field of export development, it is proposed to consider as the first vectors of the trade policy of Ukraine the following: food industry; machinery; aerospace and aviation ports and components.

\section{Food industry: niche products orientation}

The food industry is one of the most important export sectors of Ukrainian economy. It possesses an abundant resource base, human capital, established production and experience in food processing ${ }^{10}$.

Based on the market conditions development of Ukrainian food industry towards the EU is possible through production and processing of the niche products. According to the results of the market survey the cultures and commodities with the largest export potential in the EU include ${ }^{11}$ : fruits and vegetables, their processed products (for instance, vegetable purees for baby nutrition); berries; organic and bio-crops and

\footnotetext{
${ }^{10}$ Export Strategy of Ukraine: op. cit.

${ }^{11} \mathrm{~W}$. Cohen: Organic food sector in Ukraine set for takeoff, https://www.kyivpost.com/business/organic-food-sector-ukraine-set-take-off.html (access: 30.10.2018).
} 
products from them (not just corn or other trendy grains, namely niche hemp or flax); so-called healthy products: flax seeds, bran, flakes etc.; nuts; beans.

Given the growing interest of the EU in organic products, this niche may help Ukraine to develop its export competitiveness. With vast tracts of farmland, $30 \%$ of the world's coveted black soil, relatively cheap labor and geographical proximity to the EU - Ukraine has competitive advantages that could and should make it a major organics producer. Today, due to relatively low investment needs most organic producers in Ukraine are small processing enterprises and farms. In 2016 there were 390 organic farms and 421,200 ha of organic farmland. These numbers grew significantly in recent years, although just $1 \%$ of the country's total farmland is currently organic ${ }^{12}$.

Further development of organic production is limited by numerous challenges. The main problem is that Ukrainian producers have to refer to European law, which does not apply in Ukraine. Therefore, some enterprises use the term for products which do not comply to standards of the $\mathrm{EU}^{13}$.

The next problem is that Ukraine does not currently have a law governing organics, leaving the door open for confusion among consumers and fraud among producers. While the vast majority of organic producers - around $80 \%$ by some estimates - focus on export and seek EU certification, domestic sellers frequently make misleading or outright false claims, branding their products as "natural," "eco" or "bio," although it is unclear what, if anything, these labels mean. The legal vacuum enables unfair competition from companies making empty claims and confuses consumers, who often do not distinguish meaningless buzzwords from certifications that carry weight, such as the Ukrainian Organic Standard or Euro-leaf ${ }^{14}$.

There are also many economic constraints that limit the domestic market of organics. Due to higher production costs, organics tend to be more expensive than conventional products. That is why many Ukrainians are either unwilling or simply unable to pay more for specific quality. Financial limitations also impact producers. Transitioning from conventional to organic production can take up to three years and requires upfront investment. During the transition period, profitability can fall, placing stress on small and medium-sized businesses. More investment is needed to assist farmers switching to organic production. Because of this lack of investment, they cannot plan three to five years ahead. They have to survive. While some government programs have been introduced - especially in the regions - to compensate producers making the switch, many farmers are unaware of these. This transition period, along with generally higher variability in organic crop yields, can create supply-side issues, and producers often struggle to reliably provide the volumes needed by larger clients. Distribution is particularly challenging for small producers, who by some estimates grow up to $90 \%$ of the fruit

\footnotetext{
${ }^{12}$ Ibidem.

${ }^{13}$ Export Strategy of Ukraine, op.cit.

${ }^{14}$ W. Cohen, op.cit.
} 
and vegetables sold in Ukraine. Organic products spoil more quickly than conventional products, requiring particularly efficient logistics ${ }^{15}$.

There are also such obstacles as: the lack of qualified specialists (agronomists or processing technologists); non-compliance with growing technologies; the absence of serious domestic market for some types of products due to the low purchasing power of the population (i.e. the increased risk of relying exclusively on exports); logistical challenges. To realize the export potential of the niche products of the food sector of Ukraine such factors are of vital importance: cooperation of small and medium-sized producers in order to form batch of goods; systematic support of the government. Lack of information remains a key issue behind scandals involving products falsely labeled as organic, with high demand creating a temptation to fudge the facts to get the higher sale price for organics ${ }^{16}$. It is with this understanding that the government support provides for the relevant information support and the establishment of stable framework conditions, at least for the medium term ${ }^{17}$.

\section{Machinery: qualitative integration into European value chains}

In ESU Ukraine is positioned as an important industrial producer of machine building products at the international level. However, the specificity of machinery export to the EU is that its basis is made up of components and spare parts, not the final product. The key consumers of Ukrainian products are Germany (relative weight in export is 33\%) and Hungary (relative weight in export is $27 \%$ ). These two states account for $60 \%$ of Ukrainian machine-building exports to the EU. Among the other countries, to which Ukrainian machine builders supply the largest share, are Poland (relative weight in export is 6\%), Romania (relative weight in export is $6 \%$ ), the Czech Republic (relative weight in export is $6 \%$ ) and Slovakia (relative weight in export is $4 \%)^{18}$.

High competition, complex and expensive certification process for products remain major obstacles to the EU market access. At the same time, the growth of automotive and telecommunication sectors in the EU is the key driver of increase of domestic export to the EU. The best conditions for the accelerated modernization and integration of producers into European value chains have been developed in the western territories of Ukraine, where the channels of raw materials import, components and equipment were traditionally established more efficiently. Already, they are actively developing a cluster of electric goods production for the EU motor industry ${ }^{19}$. This allows us to make optimistic assumptions about the possibilities of developing well-established channels of trade cooperation between Ukraine and the EU countries and gradually

\footnotetext{
${ }^{15}$ Ibidem.

${ }^{16}$ Ibidem.

${ }^{17}$ O. Trofimtseva: Eksport do Yevropejs'koho Soiuzu: vikna mozhlyvostej [Export to European Union: windows of opportunity], http://agritrade-ukraine.com/ua/nasha-diyalnist/nashi-publikatsiji/494eksport-do-evropejskogo-soyuzu-vikna-mozhlivostej (access: 30.10.2018).

${ }^{18}$ State Fiscal Service of Ukraine, op. cit.

${ }^{19}$ V. Movchan: Scho dala Ukraini ZVT z YeS [What did FTZ with the UE give to Ukraine], http://www.ier. com.ua/ua/publications/comments?pid=5376 (access: 30.10 .2018 ).
} 
turning them into more promising in terms of participation in global networks of creation of value added forms of industrial cooperation. For example, creation of a joint system cluster in the field of machine tool building would allow the production and development of new high-precision types of machine tools with numerical software, which could become highly competitive in the world market. This would have a positive impact on the growth of economic scientific and technical capacity both of Ukraine and the EU countries, increasing their volume of high-tech export and a decrease in the level of dependence on imports of this type of products from third countries.

\section{Aerospace and aviation parts and components, including aircraft: mastering of European technologies and intra-branch trade upbuilding}

For many years, Ukraine's industry has been providing parts and components to the aviation and aerospace industries, including engines, radars, avionics and missiles, in particular to Russian enterprises for final installation in finished products. The deterioration of the geopolitical situation in the region has affected the trade of such components, with exports of "aircraft, spacecraft, and parts thereof"(HS 88) amounting to only USD 78.9 million in 2016 , or about $0.22 \%$ of Ukraine's exports of goods ${ }^{20}$. Export to the EU countries accounted for $3.3 \%$ (USD 2.6 million) ${ }^{21}$.

The Ukrainian aerospace industry has considerable potential for future growth, particularly capitalizing on the existing expertise and knowledge in the aircraft industry, including valuable aerospace industrial assets, including specialized enterprises in the area of radar and electronic warfare technology, competencies in the design, configuration and production of air defense systems. In addition, there are production centers and design houses for the missile industry in Ukraine, as well as significant competencies also exist in the field of aero engine design and engine production. Although, the sector has large capacity for further growth, particularly through accumulated knowledge and experience in the field of aviation industry, partner relations with the EU countries are poorly developed. As one indication of this is low rate of intra-industry trade ${ }^{22}$. In 2016 it was 0.29 , that is, only a third of trade with the EU fell on trade. Intra-industry trade is the initial form of vertical integration and stimulates the exchange of new technologies with the $\mathrm{EU}^{23}$. Therefore, first step towards developing a competitive aeronautics industry in Ukraine is to transfer the existing production to European standards. This will increase the scope of intra-industry trade, develop partnerships with the leading EU producers and increase the share of Ukrainian exports in the EU market.

\section{Conclusions}

The low competitiveness of Ukrainian export compared to the European one forms the current model of trade cooperation between Ukraine and the EU. Its main feature is the

\footnotetext{
${ }^{20}$ Export Strategy of Ukraine, op.cit.

${ }^{21}$ State Fiscal Service of Ukraine, op.cit.

${ }^{22}$ Export Strategy of Ukraine, op.cit.

${ }^{23}$ Ukrainian State Fiscal Service, op.cit.
} 
disproportion in technological terms. Commodity export from Ukraine is represented mainly by primary, low-technology and resource-based products. Whereas medium and high technology import and products with high added value countries are mainly imported from the EU to Ukraine. Conservation of such a model is not only viewed as having little or no future, but also threatens to exhaust the dynamics of raw materials exports, inhibit the development of new competitive export markets, reduce the incentives for foreign investment in the medium- and high-technology industries of the national economy.

The transition of the current model of trade between Ukraine and the EU into a mutually beneficial dimension requires active policy in the two directions. First, creation of favorable institutional conditions for the development of domestic business in the export-oriented sectors of the economy. Second, consultations before the adoption of trade policy measures related to the creation of preferences for the export of goods with a high level of competition between Ukrainian and European producers. In addition, the model of foreign trade should create the preconditions for the realization of their integration potential. Taking into account the state of the export-oriented sectors the opportunities to develop Ukrainian export competitiveness were identified. Among them: niche orientation of the food and beverages industry; integration of the machinery into European value chains; the development of European technologies and intrabranch trade in the aerospace and aviation parts and components industry.

\section{References}

Burakovsky I.: Ukrainian exports: the results of 2016 and future vision, http://www.ier.com.ua/ua/ publications/articles?pid=5503 (access: 20.10.2018).

Cohen W.: Organic food sector in Ukraine set for take off, https://www.kyivpost.com/business/organic-food-sector-ukraine-set-take-off.html (access: 30.10.2018).

Cox M., Alm R.: Myths of Rich \& Poor, [in:] Debating Democracy, B. Miroff et al. (Eds.), Houghton Mifflin, Boston MA 1999, pp. 320-326.

Export Strategy of Ukraine: Strategic Trade Development Road Map 2017-2021, http://me.gov.ua/Documents/Detail?lang=uk-UA\&id=e6ab10fa-0ad9-4fe4-b8be-32f570693b64\&title=EksportnaStr ategiiaUkraini-DorozhniaKartaStrategichnogoRozvitkuTorgivli2017-2021 (access: 30.09.2018).

Findlay R.: Eli Heckscher, international trade, and economic history. MIT, Cambridge MA, London 2006.

Fugazza M.: Export Performance and its Determinants: Supply and Demand Constraints, United Nation, New York, Geneva 2004.

Mikichurova O.: Implementation of the principle of mutual benefit in the process of Ukraine's integration into the European Union, Legea Si Viata 2015, No 4/3(280), pp. 57-62.

Movchan V.: Scho dala Ukraini ZVT z YeS [What did FTZ with the UE give to Ukraine], http://www.ier. com.ua/ua/publications/comments?pid=5376 (access: 30.10 .2018 ).

Porter M.E.: On competition, Harvard Businesss School Publishing, Boston MA 1998.

Ricardo D.: The principles of political economy and taxation. Dover Publications, Mineola NY 2004.

State Fiscal Service of Ukraine: Customs statistics, http://sfs.gov.ua (access: 25.10.2018).

State Statistics Service of Ukraine: Cooperation between Ukraine and EU Countries, http://www. ukrstat.gov.ua (access: 25.10.2018) 
Trofimtseva O.: Eksport do Yevropejs'koho Soiuzu: vikna mozhlyvostej [Export to European Union: windows of opportunity], http://agritrade-ukraine.com/ua/nasha-diyalnist/nashi-publikatsiji/494-eksport-do-evropejskogo-soyuzu-vikna-mozhlivostej (access: 30.10.2018).

UNCTADstat: Data center, http://unctadstat.unctad.org (access: 26.10.2018).

Vernon R.: International Investment and International Trade in the Product Cycle, Quarterly Journal of Economics 1966, No 80(2), p. 190.

World Trade Organization: Trade and tariff data, https://www.wto.org (access: 20.10.2018). 